\title{
The Attitudes of Jordanian Kindergarten Female Teachers Towards Children's Libraries
}

\author{
Luma Fakhir Abdul-Razzaq ${ }^{1}$ \\ ${ }^{1}$ Department of Library and Information Science / Zarqa University, Zarqa, Jordan \\ Correspondence: Luma Fakhir Abdul-Razzaq, Department of Library and Information Science, Zarqa University, \\ Zarqa, Jordan. E-mail: lumafakhir@yahoo.com
}

\author{
Received: April 22, 2019 \\ Accepted: May 28, 2019 \\ Online Published: June 30, 2019 \\ doi:10.5539/mas.v13n7p129 \\ URL: https://doi.org/10.5539/mas.v13n7p129
}

\begin{abstract}
The study aimed at identifying the attitudes of Jordanian female kindergarten teachers towards children's libraries. It also aimed at identifying whether there is any statistically significant difference - at the statistical significance level of $(\mathrm{a} \leq 0.05)$ - between respondents' attitudes which can be attributed to their years of experience or academic qualifications. The sample consisted of (161) out of 167 (96.4\%), female kindergarten teachers in the public schools located in Karak Governorate, Jordan. A questionnaire was used for collecting data. Several statistical methods were used.

It was found that Jordanian female kindergarten teachers in Karak Governorate have moderate attitudes towards children's libraries. It was also found that there is a statistically significant difference - at the statistical significance level of $(\mathrm{a} \leq 0.05)$ between the respondents' attitudes towards children's libraries which can be attributed to their years of experience and academic qualification.

The study recommended that more attention should be paid to achieve the goals of the Child's Library. She also recommended the need to improve the reality of the libraries, and continue to provide them with the latest sources of information allocated to children by different age groups of childhood, and secure qualified teacher/ librarians.
\end{abstract}

Keywords: attitudes, children's libraries, kindergarten female teachers, Jordan

\section{Introduction}

The childhood stage is considered the most important among the intellectual development stages. It's also considered as the best for acquiring academic and non- academic skills. That is why there are many educational institutions that aim at teaching children several skills, through many educational means. Such institutions include the children's library. The children's libraries serve as a mean for supporting children's socialization and education. If the children are provided with much knowledge, the future will be amazing and nations will have great intellectuals.

Several researchers suggest that the kindergarten stage is a significant stage. They also suggest that children during this stage must be exposed to different stimuli and acquire different experiences. Bloom suggests that the attention provided to one during his early years of life shall affect his cognitive performance in later years of his life. Thus, it is highly significant to provide children with care and education of high quality (cited in Owens, 2002).

A kindergarten child goes through several developmental stages. It is necessary to meet his needs during all the stages. Therefore, educators must select programs, and curricula that suit each stage (Qatami, 2008). Paying visits to the children's library shall also participate in meeting the child's developmental needs (Abed Al-Hamid, 2002).

Children's library plays a significant role in refining the child's talents and developing his personality, and capabilities. It also participates in guiding the child to the way he should utilize his capabilities, through adequate information sources that suit his needs, interests, and abilities, and various library services and activities, such as: storytelling, theatrical shows, and meaningful films.

Children's library is considered a very significant educational institution. For instance, it provides the child with the information, expertise, skills and thought that he needs. It will affect his attitudes to other libraries when growing up. Therefore, governments consider providing attention to children's libraries as one of their significant national responsibilities (Hassaballah, 1998). 
IFLA Library Services to Children and Young Adults Section (2018) provides that, "The purpose of the children's library is to provide resources and services in a variety of media to meet the needs of children of all ages and abilities for their education, information and personal development. This includes recreation and leisure, and also supporting children's health and wellbeing. Library services for children play an important role in the development and maintenance of a democratic society by offering the child access to a wide and varied range of knowledge, ideas and opinions."

\subsection{Statement of the Problem:}

The problem of this study is represented in exploring the effectiveness of children's libraries in developing children from the perspective of Jordanian female kindergarten teachers in Karak.

\subsection{The Study's Significance}

The present study is considered significant due to the following reasons:

1. It provides a proof about the significance of children's library.

2. It provides a theoretical framework for the researchers who want to conduct similar studies.

3. It shall enrich the literature conducted in the Arab world.

4. It provides recommendations for utilizing children's libraries effectively.

\subsection{The Study's Questions}

1)- What are the attitudes of Jordanian kindergarten female teachers towards children's libraries?

Depending on:

- The identity formation area

- The developmental area

- The social area

- The entertainment area

- The educational area

2)- Is there any statistically significant difference at $(a \leq 0.05)$ level between respondents' attitudes which can be attributed to their years of experience or academic qualifications?

\subsection{Definition of Terms}

Attitude: A set of behavioral, emotive, and cognitive elements related to one's response to a specific situation or issue. Such a response may be negative or positive (Zaytoon, 1996, p. 26).

Kindergarten female teachers: (Empirical definition): The female teachers who teach the kindergarten children at the public schools in Karak.

Children's library: It is an educational institution for promoting knowledge among children. That is done through providing a variety of information sources. It may include picture books and some beginner books. It may include a variety of audio and visual materials, films, photos, and posters that suit children.

\subsection{Limitations of the Study}

The present study was conducted during the second semester of the academic year 2018-2019. It was conducted at the Jordanian public kindergartens in Karak.

\section{The Theoretical Framework and Previous Studies}

\subsection{The Theoretical Framework}

A book serves as the oldest mean for gaining and communicating knowledge. Therefore, libraries serve as a significant source for information. However, the most important library is the one used by the child during his early years of life (i.e. the children's library). For instance, it participates in developing a reading habit among children. It also affects children's socialization positively. It positively affects children's capabilities and development in various areas. It also participates in refining the child's talents and developing his personality, through providing him with adequate information sources that suit his needs, interests, and abilities (Ahmad, 2009).

\subsection{The Goals of Children's Libraries}

Children's libraries aim at: (E'laiwy, 2006)

Providing the children with access to a broad range of books and other materials that suit them, helping and 
guiding them in choosing the suitable material, developing a reading and studying habits, language, artistic skills, and values.

In order to achieve these goals, the following requirements must be fulfilled (Abed Al-Hadi, 1988):

1. Providing a comfortable environment for reading

2. Having qualified and well-trained librarians

3. Having a broad range of information sources that were chosen carefully

4. Organizing the acquisitions of the children's library in a way that encourages the children to use it easily.

5. Providing suitable services and activities that are interesting and meaningful

\subsection{Types of Children'S Libraries}

According to (E'layan, 2006), there are many types of libraries that provide the children with their services. Some of those libraries are the public libraries, Libraries of elementary schools, kindergarten libraries classroom libraries, home library, and the bookmobile (mobile library).

\subsection{The Library'S Services Provided for Children}

The International Federation of Library Associations and Institutions (IFLA, 2001) identify several services provided by the children's libraries. They are:

1. Lending out information sources and providing access to them

2. Helping children in choosing the appropriate materials and involving children in that

3. Developing children's library-related skills

4. Carrying out motivational activities, such as: the activities that encourage children to read

5. Telling stories

\subsection{Literature Review}

\section{Arabic Literature:}

Al-Hilali and Al-Saqri (2011) found that children's libraries are effective in expanding the knowledge of Omani children. They found that children's libraries have a positive impact on children's socialization. Al-Hana'i and AlBour Sa'eedy (2011) found that children's libraries are effective in expanding Omani children's knowledge. They also found that children's libraries have a positive impact on children's personality, development and socialization.

Al-Menyawi (2009) found that kindergarten libraries play an effective role in serving the Egyptian community. The study Discussed the children's libraries, their definition and importance to the child and their role in society. She also took pictures of some of the activities presented by the library and discussed their impact on children and the community.

Murtada (2008) aimed at exploring the role of kindergarten libraries in Syria through using an observation checklist card, with areas that include: the existence of a library in the kindergarten, a qualified librarian in it, and the library's activities. It was conducted in forty (40) kindergartens located in Damascus, and concluded that the number of kindergarten libraries is inadequate, there isn't any consistency between the types of books, and the Syrian kindergarten libraries do not conduct activities.

\section{Selected Literature in English:}

Al-Harbi (2017) carried a study to identify the reality of children's libraries in Kuwait and what are the difficulties facing these libraries from the point of view of their employees. The descriptive approach was used and is best suited for such studies. In order to achieve the objectives set for this study, a structured questionnaire was prepared for this purpose, which was distributed to the study community, which consisted of (85) a teacher who responded to it (70) that is $(82.3 \%)$ of them. The results showed that the total score for estimating the employees of the children's libraries in Kuwait was medium. The results also indicated that there were no statistically significant differences at the level of significance of the study variables.

Samiei, Bush, and Imig, (2015) evaluated participation in the Imagination Library early childhood literacy enrichment program and children's pre-literacy and pre-numeracy skills at kindergarten entry in an urban school district. They found that previous studies have demonstrated that program participation is associated with greater early childhood reading practices. Results presented in this article suggest that program participation is also positively and significantly associated with higher early language and math scores, even after controlling for other 
key factors associated with kindergarten readiness. These results offer support for policy interventions designed to advance kindergarten readiness by increasing access to early literacy materials for families with young children.

McKenzie and Stooke (2012) discussed early childhood literacy activity programs run by children's libraries and community centers in the Canadian provinces of Ontario and British Columbia, focusing the ways in which these programs and children's librarians align parents' and children's goals towards literacy. The authors look at how early care providers can navigate conflicting social interactions among parents and the unintended consequences of social exclusion of parents and their children from the programs. Topics also include cooperation between library and community early learning programs, and problems of standardizing programs to the detriment of sensitive decision-making regarding children's developmental progress.

Nemec (2011) dealt with the age category in which the child must start learning and dealing with books. She concluded that the child can use the book and start learning at any age. She also emphasized the significance of providing the child with high quality services by the library. She also emphasized the significance of making the librarians of children's libraries and kindergarten teachers more qualified.

Prendergast (2011) aimed at providing information about a program for early education. This program was carried out by five librarians working at children's libraries. This program aims at developing the child's reading and writing skills during an early age through the kindergarten libraries and public children's libraries.

Bailey (2009) aimed at identifying the information sources available at the children's library. He states that such sources must suit children's age, instill positive values, and that reading during the early years of life shall participate in developing the child's personality and academic capabilities in the future.

Borawski (2009) aimed at exploring the effectiveness of learning the meaning of concepts, in developing personality and capabilities in various areas, through playing and the entertainment services that are provided by the children's library.

\section{Comments on the Aforementioned Studies}

All the aforementioned studies aimed at shedding a light on the following:

1. The significance of the kindergarten libraries

2. The role of kindergarten libraries in children's socialization and development

3. The services provided by the kindergarten libraries

4. The female librarians at the kindergarten libraries and their characteristics

There are several things that distinguish the present study from the aforementioned studies. For instance, the present study targets the female kindergarten teachers and explores their attitudes towards the effectiveness of kindergarten libraries in children's development. All these issues are not tackled by the aforementioned studies.

\subsection{Methodology}

The present study adopted a descriptive analytical approach. That was done through using a questionnaire.

\subsection{The Study's Population and Sample}

The population of the present study consisted of all the female kindergarten teachers working at the public schools located at Karak / Jordan. According to the statistics issued about the academic year (2018/2019) by the Planning Department of the Karak Directorate of Education, there are (167) female public kindergarten teachers. The questionnaire was distributed to all the members of the population. However, 159 questionnaire forms were retrieved. One questionnaire form was excluded because it was not valid for statistical analysis. Thus, the questionnaire forms that were valid for statistical analysis were (161). Thus, the response rate is $96.4 \%$.

Table (1). The number of the female kindergarten teachers in the public schools located of Karak / Jordan

\begin{tabular}{lllll}
\hline District & $\begin{array}{l}\text { The number of } \\
\text { teachers }\end{array}$ & Diploma. & BA & Postgraduate \\
\hline The southern region of Al-Mazar & 30 & 4 & 20 & 6 \\
\hline
\end{tabular}




\begin{tabular}{lllll}
\hline Al-Qaser & 35 & 5 & 22 & 8 \\
The southern region of the Jordan Valley & 18 & 3 & 12 & 3 \\
Qasabet Al-Karak & 84 & 10 & 60 & 14 \\
Totals & 167 & 22 & 114 & 31 \\
Percentage & $100 \%$ & $13 \%$ & $68 \%$ & $19 \%$ \\
\hline
\end{tabular}

Table (1) shows the distribution of the study's population according to their years of experience and qualifications

\subsection{The Study's Instruments}

A questionnaire was developed to identify the attitudes of Jordanian female kindergarten teachers at the schools located in Karak towards children's libraries. It consisted of two main parts.

The first part aimed to collect data from the respondents about their years of experience and qualifications.

The second part included items that aim at measuring the respondents' attitudes towards children's libraries.

Three multiple choice answers were provided to each item. These answers are: (agree, neutral, and disagree). The scores of these answers are (3,2, and 1) respectively

Table (2) below shows the distribution of the questionnaire items according to the variable they measure.

Table (2). The distribution of the questionnaire items according to the variable they measure

\begin{tabular}{ll}
\hline The variable & The questionnaire's statement \\
\hline The identity information areas & $1-5$ \\
The developmental areas & $6-12$ \\
The social areas & $13-20$ \\
The entertainment areas & $21-24$ \\
The educational areas & $25-36$ \\
\hline
\end{tabular}

\subsection{The Validity of the Study'S Instrument}

The researcher assessed the validity of the instrument's items through passing the instrument to a panel of experts who consists of seven (7) experts. These experts are university professors who teach at Jordanian universities. The researcher asked those experts to provide their comments. In the light of their comments, the necessary changes were made. Such changes include additions, deletions and modifications.

\subsection{The Reliability of the Study'S Instrument}

The researcher measured the reliability of the study's Instrument through using the test-re-test method. That was done through distributing the questionnaire forms to an exploratory sample that consists of twenty (20) female teachers. These teachers were chosen from outside the study's population. The questionnaire forms were distributed again to the same members of the exploratory sample after 15 days. In addition, the researcher calculated the Alpha-Cronbach as (0.86) coefficient to measure the internal consistency.

\subsection{The Study'S Variables}

\section{1)- The independent variables:}

\section{- Academic qualification}

- Years of experience

As for the Academic qualification table (3) shows that:

Table (3). The distribution of the respondent according to the Academic qualification and Experiences

\begin{tabular}{lll}
\hline Variables & frequency & percent \\
\hline Academic qualification & & \\
Diploma & 21 & $13 \%$ \\
\hline
\end{tabular}




\begin{tabular}{lll}
\hline BA & 109 & $67.7 \%$ \\
Postgraduate & 31 & $19.3 \%$ \\
total & 161 & $100 \%$ \\
Experiences & & \\
5 years and less & 64 & $39 \%$ \\
$6-10$ & 74 & $46 \%$ \\
10 years and more & 23 & $14.3 \%$ \\
total & 161 & $100 \%$ \\
\hline
\end{tabular}

There were (109) of the respondents having (BA) Degree, which makes a percentage of $67.7 \%$. (31) have postgraduate degree, that is $19.3 \%$, and (21) of them have Diploma which makes $13 \%$. That percentages indicate that most of the respondents were well educated. It can also be concluded that the largest percent of respondents (46\%) have experience of 6-10 years. And (14.3\%) of them have at least 10 years of experience.

2)- The dependent variable:

It is represented in the attitude of Jordanian female kindergarten teachers in Karak towards children's libraries

\subsection{Statistical Methods}

A)- The descriptive statistical methods: They include: means, standard deviations, percentages and frequencies

B)- Analysis of variance (ANOVA) and Scheffe test

\section{Results}

The responses were tabulated and analyzed using SSPSS statistical package. The results relating to the first question:

Q.1: What are the attitudes of Jordanian female kindergarten teachers towards children's libraries?

In order to provide an answer for this question, arithmetic means and standard deviations were calculated in accordance with each area.

Table (4). The arithmetic means and standard deviations for identifying the attitude of the respondents towards children's libraries

\begin{tabular}{llllll}
\hline $\begin{array}{l}\text { Area } \\
\text { No. }\end{array}$ & Area & $\begin{array}{l}\text { Arithmetic } \\
\text { means }\end{array}$ & $\begin{array}{l}\text { Standard } \\
\text { deviations }\end{array}$ & Rank & Level \\
\hline 5 & The educational areas & 2.31 & 0.18 & 1 & Moderate \\
3 & The social areas & 2.26 & 0.22 & 2 & Moderate \\
4 & The entertainment areas & 2.22 & 0.27 & 3 & Moderate \\
2 & The developmental areas & 2.10 & 0.30 & 4 & Moderate \\
1 & The identity formation areas & 2.08 & 0.32 & 5 & Moderate \\
Total & & 2.19 & 0.18 & \multicolumn{2}{l}{ Moderate } \\
\hline
\end{tabular}

Based on table (4), it can be concluded that the overall attitude of Jordanian female kindergarten teachers in Karak towards children's libraries is moderate due to the total mean is 2.19 . The educational areas are ranked first due to having a mean of 2.31 on a three-point Likert Scale. As for the social areas, they are ranked second due to having a mean of 2.26. As for the entertainment areas, they are ranked third due to having a mean of 2.22. As for the developmental areas, they are ranked fourth due to having a mean of 2.10 . As for the identity formation areas, they are ranked fifth due to having a mean of 2.08 .

That is based on the statistics of the following areas:

The First Area: The identity information area:

The respondents were asked to indicate their attitudes toward the five statements of this area. 
Table (5) summarizes their attitudes. The table shows that one statement got high level, and the rest four statements got moderate levels.

Table (5). Means and standard deviations concerning the statements of the questionnaire towards The identity information area

\begin{tabular}{llllll}
\hline \multirow{2}{*}{$\begin{array}{llll}\text { No. } \\
\text { The children's library develops: }\end{array}$} & Arithmetic means & Standard deviations & Rank & Level \\
\hline 1 & the child's personality & 2.36 & 0.64 & 1 & High \\
4 & the child's Tendencies & 2.18 & 0.69 & 2 & Moderate \\
5 & The child's Interests & 2.16 & 0.66 & 3 & Moderate \\
3 & the child's interests & 2.11 & 0.57 & 4 & Moderate \\
2 & the child's talent & 1.59 & 0.67 & 5 & Moderate \\
\multicolumn{2}{l}{ Total } & 2.08 & 0.66 & & \\
\hline
\end{tabular}

Based on table (5), it can be concluded that the overall attitude of Jordanian female kindergarten teachers in Karak towards the role of children's libraries in forming one's identity is Moderate. That is concluded due to having a mean of 2.08. Statement (1) is ranked first due to have a mean of 2.36 which is moderate. The latter statement states the following: (The children's library develops the child's personality). This statement is ranked first. As for statement (2), it is ranked last due to having a mean of 1.59 .

\section{Second area: The developmental area:}

The respondents were asked to indicate their attitudes toward the seven statements of this area.

Table (6) summarizes their attitudes, and shows that all statements get Moderate levels.

Table (6). The arithmetic means and standard deviations for identifying the attitude of Jordanian female kindergarten teachers in Karak towards the role of children's libraries in developing the child's developmental areas

\begin{tabular}{|c|c|c|c|c|c|}
\hline No. & $\begin{array}{l}\text { Statement } \\
\text { The children's library develops: }\end{array}$ & $\begin{array}{l}\text { Arithmetic } \\
\text { means }\end{array}$ & $\begin{array}{l}\text { Standard } \\
\text { deviations }\end{array}$ & Rank & Level \\
\hline 9 & The child's social skills & 2.24 & 0.65 & 1 & Moderate \\
\hline 12 & The child's artistic capabilities & 2.24 & 0.42 & 1 & Moderate \\
\hline 10 & $\begin{array}{l}\text { Opportunities to the children of limited } \\
\text { potentials }\end{array}$ & 2.17 & 0.64 & 3 & Moderate \\
\hline 11 & The child's creativity and talents & 2.08 & 0.68 & 4 & Moderate \\
\hline 6 & The child's scientific skills & 2.06 & 0.66 & 5 & Moderate \\
\hline 7 & The child's mental capabilities & 2.05 & 0.57 & 6 & Moderate \\
\hline 8 & The child's language capabilities & 1.85 & 0.62 & 7 & Moderate \\
\hline & Total & 2.10 & 0.30 & \multicolumn{2}{|c|}{ Moderate } \\
\hline
\end{tabular}

Based on table (6), it can be concluded that the overall attitude of Jordanian female kindergarten teachers in Karak towards the role of children's libraries in developing the child's developmental areas is Moderate. That is the total mean of the table is 2.10. As for statement (9), it shows a mean of 2.24. The latter statement states the following: (The children's library develops The child's social skills). It was ranked first. while statement number (8), ranked last due to having a mean of 1.85 .

\section{Third area: The social area:}

Table (7) summarizes their attitudes towards the role of children's libraries in developing the child in social areas. The table shows that one statement get high level, and the rest eight statements get moderate levels. 
Table (7). The arithmetic means and standard deviations for identifying the attitude of Jordanian female kindergarten teachers in Karak towards the role of children's libraries in developing the child in social areas

\begin{tabular}{clllll}
\hline No. & Statement & $\begin{array}{l}\text { Arithmetic } \\
\text { means }\end{array}$ & $\begin{array}{l}\text { Standard } \\
\text { deviations }\end{array}$ & Rank & Level \\
\hline $\mathbf{1 3}$ & $\begin{array}{l}\text { The children's library develops feeling of respect } \\
\text { towards books. }\end{array}$ & 2.3789 & 0.55839 & 1 & High \\
$\mathbf{1 8}$ & $\begin{array}{l}\text { The children's library enables children to acquire } \\
\text { positive habits }\end{array}$ & 2.3354 & 0.47360 & 2 & Moderate \\
$\mathbf{1 9}$ & $\begin{array}{l}\text { The children's library encourages the children to } \\
\text { practice Emotional activities }\end{array}$ & 2.2919 & 0.50793 & 3 & Moderate \\
$\mathbf{1 7}$ & $\begin{array}{l}\text { The children's library develops the spirit of altruism } \\
\text { within the child and encourages him to cooperate } \\
\text { with others }\end{array}$ & 2.2733 & 0.47418 & 4 & Moderate \\
$\mathbf{1 6} \quad \begin{array}{l}\text { The children's library develops the child's listening } \\
\text { skills }\end{array}$ & 2.2609 & 0.64732 & 5 & Moderate \\
$\mathbf{1 5} \quad \begin{array}{l}\text { The children's library develops the child's } \\
\text { communication skills }\end{array}$ & 2.2547 & 0.67342 & 6 & Moderate \\
$\mathbf{1 4} \quad \begin{array}{l}\text { The children's library enables children to acquire a } \\
\text { reading habit }\end{array}$ & 2.1863 & 0.57233 & 7 & Moderate \\
$\mathbf{2 0}$ & $\begin{array}{l}\text { The children's library encourages the children to } \\
\text { claim for their freedom and security }\end{array}$ & 2.1491 & 0.35727 & 8 & Moderate \\
\hline
\end{tabular}

Based on table (7), it can be concluded that the overall attitude of Jordanian female kindergarten teachers in Karak towards the role of children's libraries in developing the child in social areas is Moderate. That is because the total mean is 2.26. Statement (13) is ranked first due to having a mean of 2.37 that is high. The latter statement states the following: (The children's library develops feeling of respect towards books). while statement number (20), ranked last. That due to having a mean of 2.14.

\section{Fourth area: The entertainment area:}

Table (8) summarizes their attitudes towards the role of children's libraries in focusing on entertainment areas. The table shows that one statement get high level, and the rest three statements get moderate levels.

Table (8). The arithmetic means and standard deviations for identifying the attitude of Jordanian female kindergarten teachers in Karak towards the role of children's libraries in focusing on entertainment areas

\begin{tabular}{llllll}
\hline No. & Statement & $\begin{array}{l}\text { Arithmetic } \\
\text { means }\end{array}$ & $\begin{array}{l}\text { Standard } \\
\text { deviations }\end{array}$ & Rank & Level \\
\hline 21 & $\begin{array}{l}\text { The children's library provides various } \\
\text { entertainment methods }\end{array}$ & 2.3851 & 0.58162 & 1 & High \\
23 & $\begin{array}{l}\text { The children's library conducts competitions for } \\
\text { children }\end{array}$ & 2.1801 & 0.43140 & 2 & Moderate \\
22 & $\begin{array}{l}\text { The children's library develops the child's artistic } \\
\text { skills }\end{array}$ & 2.1739 & 0.62814 & 3 & Moderate \\
& $\begin{array}{l}\text { The children's library provides a wide space in } \\
\text { which children can move freely }\end{array}$ & 2.1739 & 0.38022 & 3 & Moderate \\
$\quad$ Total & 2.2283 & 0.27011 & & Moderate \\
\hline
\end{tabular}


Based on table (8), it can be concluded that the overall attitude of Jordanian female kindergarten teachers in Karak towards the role of children's libraries in focusing on entertainment areas is moderate. However, Statement (21) which states that," The children's library provides various entertainment methods" is ranked first due to having a mean of 2.38. which is high, Statement number (24) which states that, "The children's library provides various entertainment methods was ranked last due to having a mean of (2.17).

\section{Fifth area: The educational area:}

Table (9) summarizes their attitudes towards the role of children's libraries in developing the child in educational areas. The table shows that four statements of twelve get high level, and the rest eight statements get moderate levels.

Table (9). The arithmetic means and standard deviations for identifying the attitude of Jordanian female kindergarten teachers in Karak towards the role of children's libraries in developing the child in educational areas

\begin{tabular}{|c|c|c|c|c|c|}
\hline No. & Statement & $\begin{array}{l}\text { Arithmetic } \\
\text { means }\end{array}$ & $\begin{array}{l}\text { Standard } \\
\text { deviations }\end{array}$ & Rank & Level \\
\hline 33 & $\begin{array}{l}\text { The children's library encourages to continue } \\
\text { learning throughout life }\end{array}$ & 2.5466 & 0.51174 & 1 & High \\
\hline 25 & $\begin{array}{l}\text { The children's library conducts knowledge- } \\
\text { based activities for children }\end{array}$ & 2.4596 & 0.57002 & 2 & High \\
\hline 29 & $\begin{array}{l}\text { The children's library conducts a variety of } \\
\text { entertaining activities for children }\end{array}$ & 2.4348 & 0.50969 & 3 & High \\
\hline 36 & $\begin{array}{l}\text { The children's library expands the child's vision } \\
\text { for the future }\end{array}$ & 2.3851 & 0.50078 & 4 & High \\
\hline 30 & $\begin{array}{l}\text { The children's library promotes the family's } \\
\text { integration within the local community. It also } \\
\text { promotes the self-learning principle among } \\
\text { children }\end{array}$ & 2.3354 & 0.48662 & 5 & Moderate \\
\hline 34 & $\begin{array}{l}\text { The children's library promotes freedom of } \\
\text { choice among children in relation to the } \\
\text { material they choose to read }\end{array}$ & 2.2671 & 0.52151 & 6 & Moderate \\
\hline 28 & $\begin{array}{l}\text { The children's library provides the child with } \\
\text { knowledge and information on various areas } \\
\text { through providing a broad range of information } \\
\text { sources }\end{array}$ & 2.2609 & 0.56482 & 7 & Moderate \\
\hline 32 & $\begin{array}{l}\text { The children's library enriches the children's } \\
\text { knowledge through holding seminars, } \\
\text { workshops, lectures and debates }\end{array}$ & 2.2484 & 0.44765 & 8 & Moderate \\
\hline 35 & $\begin{array}{l}\text { The children's library participates in detecting } \\
\text { the reading problems that children suffer from }\end{array}$ & 2.2360 & 0.45436 & 9 & Moderate \\
\hline 31 & $\begin{array}{l}\text { The children's library provides a variety of } \\
\text { information sources that can fulfill the child's } \\
\text { needs }\end{array}$ & 2.2236 & 0.44687 & 10 & Moderate \\
\hline 26 & $\begin{array}{l}\text { The children's library develops the child's } \\
\text { thinking skills }\end{array}$ & 2.1925 & 0.42596 & 11 & Moderate \\
\hline 27 & $\begin{array}{l}\text { The children's library provides books and } \\
\text { information sources to the child. }\end{array}$ & 2.1863 & 0.42138 & 12 & Moderate \\
\hline & Total & 2.3147 & 0.18281 & \multicolumn{2}{|l|}{ Moderate } \\
\hline
\end{tabular}

Based on table (8), it can be concluded that the overall attitude of Jordanian female kindergarten teachers in Karak 
towards the role of children's libraries in developing the child in educational areas is Moderate. That is due to having a total mean of $(2.3147)$. Statements $(33,25,29.36)$ got the highest levels, and ranked $(1,2,3,4)$ in row, and get means of $(2.54,2.45,2.43,2.38)$. Statement number 33 which states that, "The children's library encourages to continue learning throughout his life" was ranked first. As for statement 27, it is ranked last. That due to having mean of 2.18. The latter statement states the following: (The children's library provides books and information sources to the child). Those means indicate that there is much agreement on the statements of this area.

\section{Results Related the Second Question:}

Q.2: Is there any statistically significant difference - at the statistical significance level of $(a \leq 0.05)$ between the attitudes of Jordanian female kindergarten teachers in Karak towards children's libraries which can be attributed to their years of experience or academic qualification?

In order to provide an answer for question (2), the two-way analysis of variance was conducted for each area and all the areas jointly according to the respondents' academic qualification and years of experience.

Table (10). The arithmetic means and standard deviations for the attitudes of female kindergarten teachers in Karak towards children's libraries according to their academic qualification and years of experience

\begin{tabular}{|c|c|c|c|}
\hline Variable & Category & $\begin{array}{l}\text { Arithmetic } \\
\text { mean }\end{array}$ & $\begin{array}{l}\text { Standard } \\
\text { deviation }\end{array}$ \\
\hline \multirow{4}{*}{$\begin{array}{l}\text { Academic } \\
\text { qualification }\end{array}$} & diploma & 2.0079 & .14680 \\
\hline & Bachelor degree & 2.1817 & .16154 \\
\hline & Postgraduate degrees & 2.3933 & .11758 \\
\hline & Total & 2.1998 & .18765 \\
\hline \multirow{4}{*}{$\begin{array}{ll}\text { Years } & \text { of } \\
\text { experience }\end{array}$} & Five years of experience or less & 2.2404 & .18859 \\
\hline & 6 - less than 10 years of experience & 2.2045 & .16348 \\
\hline & More than 10 years of experience & 2.0713 & .20838 \\
\hline & Total & 2.1998 & .18765 \\
\hline
\end{tabular}

Based on table (10), it appears that there are differences between means. Thus, the two-way analysis of variance was conducted to identify whether these differences are statistically significant. Table (11) shows the results of the two-way analysis of variance

Table (11). ANOVA of Mean Scores on Attitudes of respondents by academic qualifications

\begin{tabular}{llllll}
\hline & Sum of Squares & df & Mean Square & F & Sig. \\
\hline Between Groups & 1.970 & 2 & .985 & 42.468 & $.000^{*}$ \\
Within Groups & 3.664 & 158 & .023 & & \\
Total & 5.634 & 160 & & & \\
\hline
\end{tabular}

Table (11) indicates that there are statistically significant differences $(\alpha \leq 0.05)$ in the level of the trends of kindergartens in Karak towards the children's library due to the variable of the Academic qualification based on the calculated value of sig (0.000). In order to determine the variance of the differences, the Scheffe test was used, and Table (12) shows the results of this post-hoc test.

Table (12). The results of Scheffe test for post hoc comparisons 


\begin{tabular}{|c|c|c|c|c|c|c|}
\hline \multirow[b]{2}{*}{ (I) edulvl } & \multirow[b]{2}{*}{ (J) edulvl } & Mean Difference & \multirow{2}{*}{ Std. Error } & \multirow[b]{2}{*}{ Sig. } & \multicolumn{2}{|c|}{ 95\% Confidence Interval } \\
\hline & & $(\mathrm{I}-\mathrm{J})$ & & & Lower Bound & Upper Bound \\
\hline \multirow[t]{2}{*}{1.00} & 2.00 & $-.17376-^{*}$ & .03629 & .000 & $-.2634-$ & $-.0841-$ \\
\hline & 3.00 & $-.38539-^{*}$ & .04304 & .000 & $-.4917-$ & $-.2790-$ \\
\hline \multirow[t]{2}{*}{2.00} & 1.00 & $.17376^{*}$ & .03629 & .000 & .0841 & .2634 \\
\hline & 3.00 & $-.21163-^{*}$ & .03100 & .000 & $-.2882-$ & $-.1350-$ \\
\hline \multirow[t]{2}{*}{3.00} & 1.00 & $.38539^{*}$ & .04304 & .000 & .2790 & .4917 \\
\hline & 2.00 & $.21163^{*}$ & .03100 & .000 & .1350 & .2882 \\
\hline
\end{tabular}

*. The mean difference is significant at the 0.05 level.

Based on Table 12, it can be concluded that there are statistically significant differences between the positions of diploma, bachelor or postgraduate. The averages indicate that the differences were in favor of the post-graduate, where they obtained the highest averages (2.39).

Table (13).

\begin{tabular}{llllll}
\hline & Sum of Squares & $\mathrm{df}$ & Mean Square & $\mathrm{F}$ & Sig. \\
\hline Between Groups & .487 & 2 & .244 & 7.475 & .001 \\
Within Groups & 5.147 & 158 & .033 & & \\
Total & 5.634 & 160 & & & \\
\hline
\end{tabular}

Table (13) indicates that there are statistically significant differences $(\alpha \leq 0.05)$ in the level of trends of kindergartens in Karak towards the children's library due to the variable of the experience based on the calculated value of (f) at (7.475). In order to know the variance of the differences, the Scheffe test was used, and Table 14 shows the results of this post-hoc test.

Table (14). Multiple Comparisons

Scheffe

\begin{tabular}{lllllll}
\hline & \multicolumn{3}{l}{ Mean Difference } & \multicolumn{2}{l}{$95 \%$ Confidence Interval } \\
\cline { 5 - 7 }$(\mathrm{I}) \exp$ & $(\mathrm{J}) \exp$ & $(\mathrm{I}-\mathrm{J})$ & Std. Error & Sig. & Lower Bound & Upper Bound \\
1.00 & 2.00 & .03590 & .03081 & .509 & $-.0402-$ & .1120 \\
& 3.00 & $.16912^{*}$ & .04388 & .001 & .0607 & .2775 \\
2.00 & 1.00 & $-.03590-$ & .03081 & .509 & $-.1120-$ & .0402 \\
& 3.00 & $.13321^{*}$ & .04309 & .010 & .0267 & .2397 \\
3.00 & 1.00 & $-.16912-^{*}$ & .04388 & .001 & $-.2775-$ & $-.0607-$ \\
& 2.00 & $-.13321-^{*}$ & .04309 & .010 & $-.2397-$ & $-.0267-$ \\
\hline
\end{tabular}

*. The mean difference is significant at the 0.05 level.

Table (14) shows that there are statistically significant differences at the level $(\alpha \leq 0.05)$ due to the variable of the scientific qualification for the holders of the postgraduate certificate, as it obtained the highest mean of (2.3933) as indicated in Table (10).

\section{Discussion and Analysis}

\subsection{Discussion Related to the First Question}

The results show that the mean of the overall attitude of respondents towards children's libraries is moderate. That is because the schools located in the southern regions of Jordan provide some attention to the children's libraries 
due to their impact on the child's comprehension skills. This attention indicates that the teacher's performance in carrying out the library-related activities is medium and there is willingness to improve their activities. The expected performance shall be reflected positively on the child.

It should be noted that childhood is considered the most important age category for achieving intellectual development and developing academic and non- academic skills. During this stage, the library plays a significant role in developing one's personality. The library can achieve such development through providing children with books, photos, and meaningful films. The results of the first question are in agreement with the results concluded by Al-Hilali and Al-Saqri (2011) and Al-Hana'i and Al-Bour Sa'eedy (2011).

It was found that the overall attitude of Jordanian female kindergarten teachers in Karak towards the role of children's libraries in developing the child in educational areas is moderate with a total mean of (2.31). To illustrate more, it was concluded that respondents highly believe that the children's library provides a variety of information sources that can fulfill the child's needs. Respondents also believe that the children's library provides the child with knowledge and information on various areas and develops his thinking skills. They also believe that the children's library conducts knowledge-based activities for children. It was also concluded that respondents believe that the children's library expands the children's vision for the future and promotes the self-learning principle among them.

It was concluded that the overall attitude of the Jordanian female kindergarten teachers in Karak towards the role of children's libraries in developing the child in social areas is moderate. To illustrate more, it was concluded that the children's library participates in developing the child's communication and listening kills. It also enables the child to acquire positive habits. It was concluded that the children's library encourages children to practice religious activities and acquire a reading habit.

It was found also that the attitude of respondents towards the role of children's libraries in focusing on entertainment areas is moderate. To illustrate more, it was concluded that respondents highly believe that children's library develops the child's artistic skills and promotes the competitive spirit through competing fairly. This spirit is promoted through holding competitions, and carrying out a variety of entertaining activities to children. It was concluded that respondents highly believe that the children's library encourages children to read during their free time.

It was concluded that the overall attitude of respondents towards the role of children's libraries in developing the child in several developmental areas is moderate. To illustrate more, it was concluded that the children's library participates in developing the child's language, social, and academic skills. It also participates in developing the child's creativity and talents.

It can be concluded that the overall attitude of Jordanian female kindergarten teachers in Karak towards the role of children's libraries in forming child's identity is moderate. Statement (1) is ranked first and statement (2) is ranked last. Statement (1) states the following: (The children's library develops the child's personality). It was concluded that respondents realize that the children's library plays a significant role in forming the child's identity. In addition, it is confirmed that the children's library develops the child's cognition, and personality. It is also confirmed that the children's library can refine the child's talent and develop his inclinations.

\subsection{Discussion Related to the Second Question}

It was concluded that there is statistically significant difference between the attitudes of respondents towards children's libraries attributed to their academic qualification and years of experience. However, it was concluded that there are statistically significant differences between the attitudes of respondents towards children's libraries which can be attributed to their academic qualifications. That is because the respondents have adequate years of experience that enable them to realize the significant role that the children's library plays in the children's socialization. In addition, the respondents' years of experience have enable respondents to identify the significance of the children's library. These years enable respondents to identify the way of providing library services efficiently to children. Providing the library services efficiently involves choosing the right books, and helping children in choosing the suitable reading material. Providing library services efficiently also involves encouraging the children to read and helping them to develop their personal capabilities and social values. In other words, it was concluded that there is a positive relationship between the years of experience of the Jordanian female kindergarten teachers and their ability to meet the goals of the children's library.

It was concluded that there is a positive relationship between the Jordanian female kindergarten teachers and their ability to identify the factors that have a positive impact on work. It was concluded that there is a positive relationship between the Jordanian female kindergarten teachers and how responsible and dedicated they are. It 
should be noted that the female teachers who have higher academic qualification are capable to provide the services of the children's library more efficiently than others. They are also able to meet the library's goals targeting children. They are more able to meet the children's needs, and make them desire to visit the library. They are also more able to promote respect among children to the library.

The ones with higher academic qualifications are more able to create an environment at the children's library that is suitable for reading, entertaining and acquiring new positive habits and values. Such values and habits may include: self-reliance, and reading habit.

\section{Recommendations}

Based on the results of this study, which indicate that the overall attitude of the respondents towards the role of children's libraries is moderate, which means that much effort is needed, the researcher of the present study recommends the following.

The researcher of the present study recommends the following:

1. Exerting more efforts to develop the children's libraries and providing them with more attention. That can be done through providing them with the most recent information sources that suit children.

2. Providing more attention to the services provided by the children's libraries

3. Training the female kindergarten teachers and librarians about the way of providing the services of the children's libraries efficiently.

4. Conducting more studies about children's libraries in order to provide the best services to children.

\section{References}

\section{The References Conducted in Arabic Language}

Abed, Al-Hadi, M. F. (1988). Studies about libraries and information. Al-Mareekh publishing house, p. 129 -30.

Abed, A., \& Mohammad, I. (2002). Assessment of some kindergarten institutions in the light of children's need to grow during the pre-school stage, The Journal of psychology, July - August - September, p.64 -86.

Ahmad, S. A. A. (2009). Children's literature: A theoretical review and empirical methods. Dar Al-Maseera publishing house, Jordan, Amman, page 270.

Al-Hana'I, A. S., \& Al-Bour, S., \& Mohammad, b. K. (2011). Libraries and their role in knowledge development among the Omani children. A symposium titled (the knowledge of the Omani child), Sultan Qaboos University, $16-9$ October.

Al-Harbi, A. N. (2017). The reality of children's libraries in the State of Kuwait and the situation facing them from the perspective of its employees. Arab Journal of Scientific \& Research Publishing, 2(1), 125-147.

Al-Hilali, M. M., \& Al-Saqri, M. N. (2011). The role of children's libraries in knowledge development among the Omani children. A symposium titled (the knowledge of the Omani child), Sultan Qaboos University, 16-9 October.

Al-Menyawi, H. M. (2009). Children's libraries and their role in serving community (Arab Hamdi library), The Thirteenth conference of the Egyptian Association for Libraries and Information (The library and community in Egypt), Al-Arish, Egypt, July 5 - 7.

E'laiwy, M. O. (2006). The quality libraries: The national, university, specialized, public, and school libraries. Al-Waraq publishing house, Jordan, Amman, 2006, p.148 -49.

E'layan, R. M. (2006). The services of children's libraries: A case study for children's storytelling. The Journal of King Fahad National Library, 12(1), 245-246

Murtada, S. (2008). The state of kindergarten libraries and the prospects of its development: A field study conducted in the kindergarten of Damascus. The Journal of Damascus University, 24(1), 15-51.

Zaytoon, A. M. (1996). The methods of teaching science (2nd ed.). Dar Al-Shorouq Publishing house, Jordan, Amman.

\section{The References Conducted in English Language}

Bailey, A. R. (2009). Early Essentials: Developing and Sustaining Birth-Kindergarten Library Collections. Children \& libraries, 7(3), 17-20.

Borawski, C., \& others (2009). Going for Games: What Libraries, and Kids, Can Learn about Games. Children \& 
Libraries, 7(1), 48-50.

Hassaballa, H., Gorelick, P. B., West, C. P., Hansen, M. D., \& Adams, H. P. (1998). Ischemic stroke outcome. Racial, 37(18), 4666-4671.

IFLA Library Services to Children and Young Adults Section (2018). IFLA Guidelines for Library Services to Children aged 0-18. p.5. Retrieved April 1, 2019, from https://www.ifla.org/files/assets/libraries-for-childrenand-ya/publications/ifla-guidelines-for-library-services-to-children_aged-0-18.pdf

McKenzie, P. J., \& Stook, R. (2012). Making a Difference the Importance of Purposes to Early Learning Programs. Children \& Libraries. The Journal of the Association for Library Service to Children, 10(2), 47-52.

Nemec, J. (2011). It's (Still) Never Too Early to Start. Children \& Libraries, 9(3), 15-21.

Owens, K. B. (2000). Child \& Adolescent development .An integrated approach). Australia: Wadsworth, Thomson learning

Prendergast, T. (2011). Beyond Story time: children's librarians collaborating in communities. Children \& libraries, 9(1), 20-40.

Samiei, S., Bush, A. J., \& Imig, D. (2015). Examining the association between the imagination library early childhood literacy program and kindergarten readiness, Reading Psychology, 37(4), 601-626.

The general guidelines of the services of children's libraries - The department of libraries of children and juveniles (2001), p.5

\section{Copyrights}

Copyright for this article is retained by the author(s), with first publication rights granted to the journal.

This is an open-access article distributed under the terms and conditions of the Creative Commons Attribution license (http://creativecommons.org/licenses/by/4.0/). 